\title{
A Systematic Analysis of Detection of Autism Spectrum Disorder: IOT Perspective
}

\author{
Narinder Kaur, Amandeep Kaur, Neha Dhiman, Anupam Sharma, Rupika Rana
}

\begin{abstract}
Purpose: Research interest in Internet of things (IOT) and autism spectrum disorder (ASD) has grown. In this literature, we will discuss how computer technologies can recover the life value of the people with the Autism. There is a requirement to analyze the literature to let computer technologies reflect their applicability. The literature target was to study nature and results of studies probing IOT valuation in ASD.Technique: A systematic examination of the different literature was carried out, in which 7 studies are matched with an inclusion criteria. Information was taken out by authors from every involved article, containing characteristics of the participant, use of technology, actions and reported results. Superiority literature of all the articles was carried out.Result: The 284 participants with autism spectrum disorder across the 7 involved studies include the participant with the age from 6 months to middle age. The quality of the studies varied. A variety of services were delivered via IOT, including diagnostic assessment and early detection. Results suggested that services delivered through various internets of things were equal to services provided face to face, and higher to human techniques. Conclusion: The suggested outcomes might be a sequence of benefits with the use of internet of things with individuals suffering from ASD, their families, and trainers. Additional research is essential mainly regarding the usage of IOT openly with kids with ASD for the assessment and involvement.

Keywords: ASD, autism spectrum disorder, IOT, Internet of things, detection
\end{abstract}

\section{INTRODUCTION}

Autism spectrum disorder (ASD) is a neural and progressive disorder that initiates in childhood and persists all over a person's lifespan. It affects person activities and acts together with others, converses, and learns. It comprises what used to be recognized as Asperger syndrome and pervasive developmental disorders.

It is titled as a "spectrum" disorder since persons with Autism Spectrum Disorder can have variety of symptoms. Individuals with ASD might have difficulties in conversation, or they may not stare you when communication is done with them. They might feel restricted comforts and monotonous behaviors. They may devote lots of period placing stuffs in order, or else they might replication the same sentence over and over. They may often seems to be in their "own world."

Revised Manuscript Received on April 22, 2019.

* Correspondence Author

Ms. Narinder Kaur*, PhD Scholar, Chandigarh Univversity, B.TECH, MTECH in field of Computer science and Technology having Experience

Dr. Amandeep Kaur, computer science and engineering from Punjabi University Patiala.

Ms. Neha Dhiman, Assistant Professor, in computer science and engineering CGC Jhanjeri having

Ms. Anupam Sharma, Assistant Professor, in computer science and engineering CGC Jhanjeri

Mrs. Rupika Rana, Assistant Professor, CGC Jhanjeri

(C) The Authors. Published by Blue Eyes Intelligence Engineering and Sciences Publication (BEIESP). This is an open access article under the CC BY-NC-ND license (http://creativecommons.org/licenses/by-nc-nd/4.0/)
Numerous reasons may affect the growth of autism, and it is frequently accompanied by sensory sensitivities and medical issues such as seizures or sleep syndromes, gastrointestinal (GI) disorders, , alongside with mental health defies such as depression ,anxiety, and attention issues.

Signs of autism usually appear by age of 2 or 3 . Numerous associated development deferrals can give the impression even earlier, and over and over again. Early age to identify ASD is 18 months.

\section{METHODOLOGY FOR SELECTION CRITERIA}

The Reporting Articles for Systematic Literatures and Meta-Analyses (PRISMA) statement was cast-off to guide the process of systematic literature (see Figure 1). A systematic examine of relevant studies was piloted in databases IEEE, PubMed, Web of Science from 2012 through October 2019 and was not limited by language. Titles and abstracts were searched using key words to describe IOT and ASD are as below:

1. ("Autism" AND "IOT")

2. ("Autism spectrum disorder" OR "internet of things")

3. ("Autism" AND "internet of things")

4. ("Autism spectrum disorder" OR "IOT")

An entire 30 papers that comprised of both the IOT and autism search terms were originated across the three databases. Later removing the duplicates, 26 remained. Abstracts and Headings were separated on the basis of present inclusion a criterion which includes:

(a) Addition of as a minimum one person with autism or parent of an individual with autism

(b) Application of IOT system for the purpose of assessment or intervention;

(c) Utilization of a design that lets detection of autism using different internet of things.

(d) Quantity of factors related with IOT implementation (such as feasibility, child and parent outcomes);

(e) Article with peer literature journal publishing.

List of Exclusion criteria includes:

I. Non- human participants studies

II. Articles available in languages except English

III. Articles that are not concerned with detection of autism

No limitation on date of publication was preferred. On screening the 284 papers depending on heading and abstract, 26 papers persisted. Following literature, 7 papers persisted that bump into all criteria. The first author mined the following data from each involved article: applicant characteristics (gender age, analysis), use of technology, and, the methodology/design, actions and testified outcomes. 
A Systematic Analysis of Detection of Autism Spectrum Disorder: IOT Perspective

Table 1: Results of the systematic literature.

\begin{tabular}{|c|c|c|c|c|c|}
\hline References & $\begin{array}{l}\text { Characteri } \\
\text { stics of } \\
\text { Participan } \\
\text { t }\end{array}$ & Technology & Design/method & Parameters & $\begin{array}{l}\text { Reported } \\
\text { outcomes }\end{array}$ \\
\hline $\begin{array}{l}\text { Saini, Rajkumar Kumar, } \\
\text { Pradeep } \\
\text { Kaur, Barjinder Roy, } \\
\text { Partha Pratim Dogra, Debi } \\
\text { Prosad Santosh, K C }\end{array}$ & $\begin{array}{l}\text { two } \\
\text { persons }\end{array}$ & $\begin{array}{l}\text { Kinect } \\
\text { sensor-based } \\
\text { interaction } \\
\text { monitoring system }\end{array}$ & $\begin{array}{l}\text { Bidirectional long } \\
\text { short-term } \\
\text { memory neural } \\
\text { network } \\
\text { (BLSTM-NN). }\end{array}$ & & $\begin{array}{l}\text { The overall } \\
\text { performance of } \\
\text { the system } \\
\text { recorded as } \\
70.72 \% \\
\text { when }\end{array}$ \\
\hline $\begin{array}{l}\text { Alam, Md. Eftekhar } \\
\text { Kaiser, M Shamim } \\
\text { Hossain, Mohammad } \\
\text { Shahadat } \\
\text { Andersson, Karl }\end{array}$ & - & $\begin{array}{l}\text { IoT-Belief Rule } \\
\text { Base Smart } \\
\text { System }\end{array}$ & & $\begin{array}{l}\text { knowledge } \\
\text { representation } \\
\text { parameters such as } \\
\text { rule } \\
\text { weight, attribute } \\
\text { weight and degree } \\
\text { of belief }\end{array}$ & \\
\hline $\begin{array}{l}\text { Shi, Yan } \\
\text { Das, Saptarshi } \\
\text { Douglas, Sarah } \\
\text { Biswas, Subir }\end{array}$ & Classroom & $\begin{array}{l}\text { wearable sensor } \\
\text { system }\end{array}$ & $\begin{array}{l}\text { data-driven } \\
\text { detection, therapy, } \\
\text { intervention, and } \\
\text { progress } \\
\text { monitoring }\end{array}$ & $\begin{array}{l}\text { quantified data } \\
\text { about interactions } \\
\text { among children }\end{array}$ & \\
\hline $\begin{array}{l}\text { Amiri, Amir Mohammad } \\
\text { Peltier, Nicholas } \\
\text { Goldberg, Cody } \\
\text { Sun, Yan } \\
\text { Nathan, Anoo } \\
\text { Hiremath, Shivayogi V } \\
\text { Mankodiya, Kunal }\end{array}$ & 3 children & $\begin{array}{l}\text { modern } \\
\text { smartwatches }\end{array}$ & $\begin{array}{l}\text { record the } \\
\text { accelerometer data } \\
\text { from the } \\
\text { smartwatch worn } \\
\text { on the wrist }\end{array}$ & $\begin{array}{l}\text { stereotypic } \\
\text { behaviors }\end{array}$ & around $94.6 \%$. \\
\hline $\begin{array}{l}\text { Rahman, M A } \\
\text { Bhuiyan, M }\end{array}$ & & $\begin{array}{l}\text { structured sensor } \\
\text { platform }\end{array}$ & & $\begin{array}{l}\text { uploads the } \\
\text { collected } \\
\text { bio-feedback } \\
\text { signals }\end{array}$ & \\
\hline $\begin{array}{l}\text { Min, Cheol-Hong } \\
\text { Tewfik, Ahmed H } \\
\text { Kim, Youngchun } \\
\text { Menard, Rigel }\end{array}$ & 2 children & $\begin{array}{l}\text { Optimal sensor } \\
\text { location }\end{array}$ & $\begin{array}{l}\text { finding optimal } \\
\text { detection } \\
\text { performance based } \\
\text { on sensor location } \\
\text { and number of } \\
\text { sensors }\end{array}$ & $\begin{array}{l}\text { stereotypical } \\
\text { self-stimulatory } \\
\text { behavioral } \\
\text { patterns of } \\
\text { children }\end{array}$ & $86.5 \%$ accuracy \\
\hline Tang, Tiffany Y & & $\begin{array}{l}\text { Kinect V2's HD } \\
\text { Face API) }\end{array}$ & perceive emotions & $\begin{array}{l}\text { Facial expressions } \\
\text { and body } \\
\text { movement. }\end{array}$ & \\
\hline $\begin{array}{l}\text { Ahlstrom, Britt H } \\
\text { Wentz, Elisabet }\end{array}$ & $\begin{array}{l}\text { Twelve } \\
\text { young } \\
\text { persons ( } 7 \\
\text { males and } 5 \\
\text { females) }\end{array}$ & $\begin{array}{l}\text { Internet-based } \\
\text { chat logs }\end{array}$ & $\begin{array}{l}\text { A qualitative } \\
\text { methodology }\end{array}$ & $\begin{array}{l}\text { analyses of } \\
\text { Internet-based } \\
\text { chat logs }\end{array}$ & \\
\hline
\end{tabular}




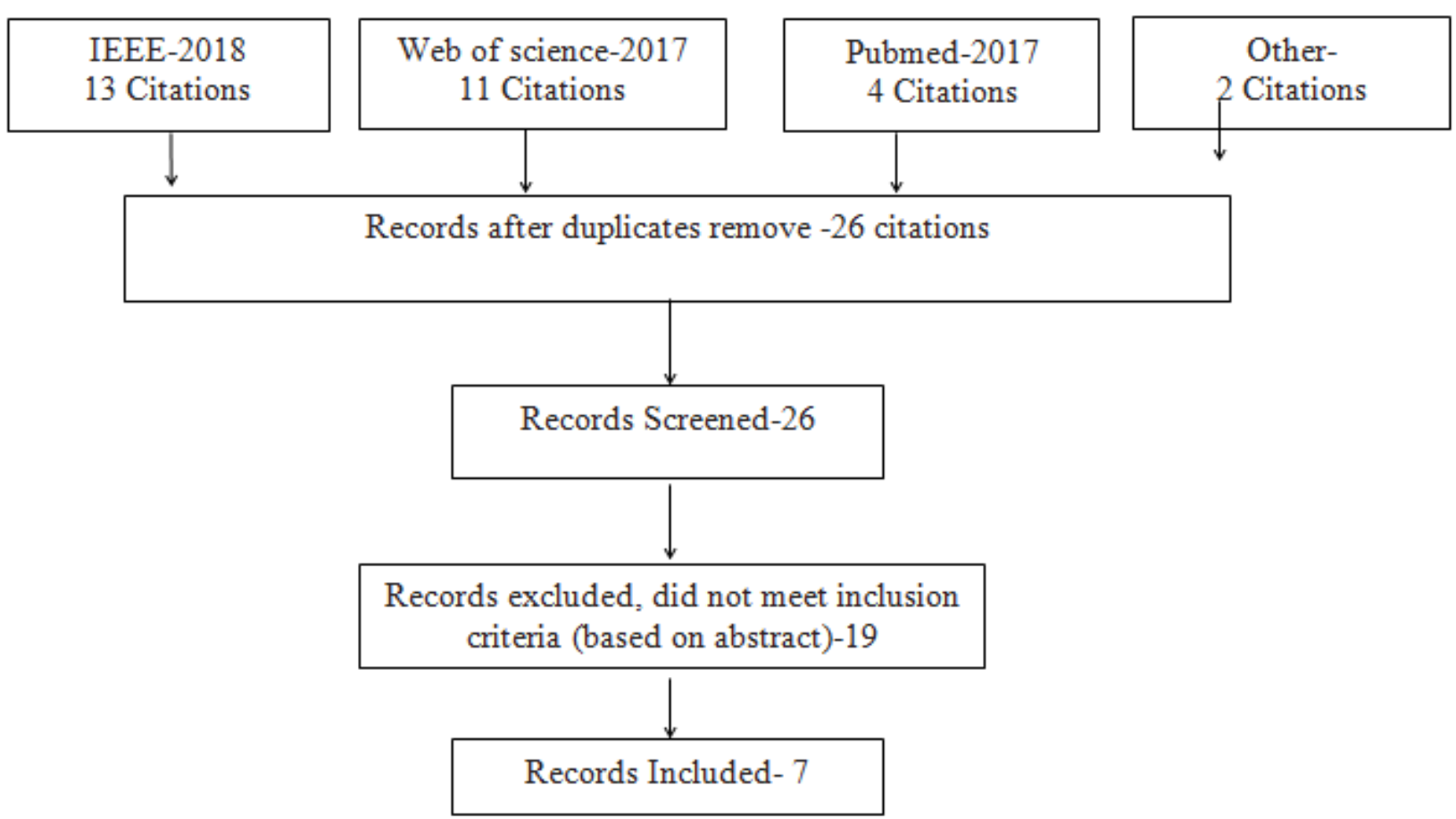

Figure 1 Summary of Systematic Literatures and Meta-Analyses (PRISMA) article screening process.

\section{RESULT}

The information of the included literature are potted in Table I. Number of articles were published between 2012 and 2019, across a varieties of discipline. The result is calculated on the basis of literatures with their respective

Characteristics of Participant, Technology,

Design/method, Parameters and Reported outcomes. The result is brief due to less research work in this particular field. The judgment for best IOT is calculated on the basis of accuracy of the performance of IOT.

\section{PARTICIPANT CHARACTERISTICS}

Applicants with ASD were involved with internet of things directly and actively in approximately all the studies: whole classroom were participants in one study that uses wearable sensor system for data-driven detection, therapy, intervention, and progress monitoring (Shi, Das, Douglas, \& Biswas, 2017), a children aged less than 11 years was engaged in use of modern smart watches and Optimal sensor (Amiri et al., 2017) and (Min, Tewfik, Kim, \& Menard, 2009), and; 12 young people were involved with use of Internet-based chat logs(Ahlstrom \& Wentz, 2014).

\section{TECHNOLOGY}

The most of the studies utilized standard, freely available equipment, wearable sensor system, modern smart watches and Internet-based chat logs. Some of the studies use Face API and IoT-Belief Rule Base Smart System and many more.

\section{PARAMETERS}

Different parametres were analyzed in these 7 studies. One of the above literature incorporates knowledge factors such as, attributes weight , degree of belief and rule weight , and classifies the children having autism based on the sign and symptoms (Alam, Kaiser, Hossain, \& Andersson, 2018). Another one monitors the social interaction progress of children with ASD through observational methods (Shi et al., 2017). In Some of the studies, the gathered bio-feedback signals were uploaded for further analysis, preservation and extended remote support (Rahman \& Bhuiyan, 2015). And one of these studies detected self-injurious behaviors of patients and stereotypical self-stimulatory behaviors (stereotypy) and with Autistic behaviors (Min \& Tewfik, 2010). One of the research focuses on investigating their deficiencies level to observe emotions through movement of the body and facial expressions (Tang, 2016).

\section{LIMITATIONS}

The present examination was narrowed by the minor included studies and a meta-analysis of results was not accomplished in the present study. Despite the development in research and interest in the use of IOT, only 7 studies come across the inclusion benchmarks for this literature. As an end result, the conclusions of study must be taken with attentiveness. Additionally, there was a variety of service types measured in the included studies. The data are also restricted by existence of grey and unpublished literature.

\section{CONCLUSION}

The outcomes of above literature proposed that internet of things endure to be a favorable part of practice for persons on the autism spectrum disorder. Research of internet of things in the earlier nine years have concentrated intensely on the delivery of IOT instruction to caregivers, parents, and teachers around a series of provision types and employing enormous study designs.

Published By:

Blue Eyes Intelligence Engineering 
Though, There are holes in the study that impending studies could ponder. First is survey of

the role of IOT in providing straight services to individuals with Autism spectrum disorder. Limited papers have scrutinized the responses and behaviors of kids and younger generation on the autism when in case with IOT services. Lastly, although the studies involved in the present literature stated high degrees of participant gratification, further studies should linger to discover the helpers and barriers to the use of internet of things with parents, clinicians and

persons on the ASD.

\section{ACKNOWLEDGMENT}

First author would like to extend her special thanks of gratitude to her mentor Dr. Amandeep Kaur who furnished her with the golden chance to work on this magnificent project on the above mentioned topic. I am very much thankful for them. Moreover, I would also like to show gratitude to my family who help out me a lot in completing this project within the limited time frame. During the process of writing this paper, I have tried to be updated with the technology and also started exploring the new possible areas for implementation of technology.

\section{REFERENCES}

1. Ahlstrom, B. H., \& Wentz, E. (2014). Difficulties in everyday life: young persons with attention-deficit/hyperactivity disorder and autism spectrum disorders perspectives. A chat-log analysis. International Journal of Qualitative Studies on Health and Well-Being, 9, 23376. https://doi.org/10.3402/qhw.v9.23376

2. Alam, M. E., Kaiser, M. S., Hossain, M. S., \& Andersson, K. (2018). An IoT-Belief Rule Base Smart System to Assess Autism. 2018 4TH INTERNATIONAL CONFERENCE ON ELECTRICAL ENGINEERING AND INFORMATION \& COMMUNICATION TECHNOLOGY (ICEEICT), 671-675. 345 E 47TH ST, NEW YORK, NY 10017 USA: IEEE.

3. Amiri, A. M., Peltier, N., Goldberg, C., Sun, Y., Nathan, A., Hiremath, S. V, \& Mankodiya, K. (2017). WearSense: Detecting Autism Stereotypic Behaviors through Smartwatches. HEALTHCARE, 5(1). https://doi.org/10.3390/healthcare5010011

4. Rahman, M. A., \& Bhuiyan, M. (2015). IOT enabled sensor in multimodal intelligent applications for children with special needs. 2015 Internet Technologies and Applications (ITA), 352-357. https://doi.org/10.1109/ITechA.2015.7317425

5. Saini, R., Kumar, P., Kaur, B., Roy, P. P., Dogra, D. P., \& Santosh, K. C. (2019). Kinect sensor-based interaction monitoring system using the BLSTM neural network in healthcare. INTERNATIONAL JOURNAL OF MACHINE LEARNING AND CYBERNETICS, 10(9), 2529-2540. https://doi.org/10.1007/s13042-018-0887-5

6. Shi, Y., Das, S., Douglas, S., \& Biswas, S. (2017). An Experimental Wearable IoT for Data-driven Management of Autism. 2017 9TH INTERNATIONAL CONFERENCE ON COMMUNICATION SYSTEMS AND NETWORKS (COMSNETS), 468-471. 345 E 47TH ST, NEW YORK, NY 10017 USA: IEEE.

7. Tang, T. Y. (2016). Helping Neuro-typical Individuals to "Read\{"\} the Emotion of Children with Autism Spectrum Disorder: an Internet of-Things Approach. PROCEEDINGS OF THE 15TH INTERNATIONAL CONFERENCE ON INTERACTION DESIGN AND CHILDREN (IDC2016), 666-671. https://doi.org/10.1145/2930674.2936009

8. www.ieeexplore.ieee.org - for reference on how to write a paper.

9. www.scholar.google.com - for exploring existing papers on my topic.

10. https://www.webmd.com/brain/autism/autism-spectrum-disorders

11. https://www.techopedia.com/definition/190/artificial-intelligence-ai

12. https://semielectronics.com/sensors-lifeblood-internet-things

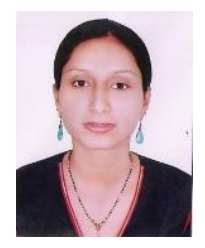

\section{AUTHORS PROFILE}

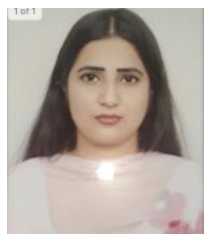

Dr. Amandeep Kaur, Phd, in computer science and engineering from Punjabi University Patiala. She is working as Associate professor in CSE in Chandigarh University

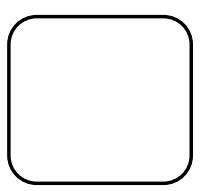

Ms. Neha Dhiman, Assistant Professor, in computer science and engineering CGC Jhanjeri having experience of 2 yrs.

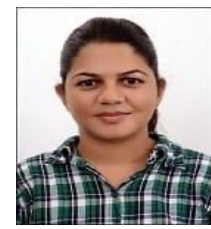

Ms. Anupam Sharma, Assistant Professor, in computer science and engineering CGC Jhanjeri having experience of 6 yrs.

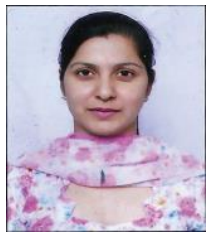

Mrs. Rupika Rana, Assistant Professor, CGC Jhanjeri having experience of 6 yrs. 